\title{
PENGATURAN RUANG TERBUKA HIJAU BERDASARKAN PERATURAN DAERAH KOTA DENPASAR NOMOR 27 TAHUN 2011
}

\author{
Ni Putu Feggy Cintya Karna, I Ketut Sukadana, I Nyoman Sutama \\ Fakultas Hukum Universitas Warmadewa, Denpasar - Bali, Indonesia
}

\begin{abstract}
Abstrak
Kawasan perkotaan pada saat ini telah menjadi masalah yang cukup sulit diatasi, terutama dalam bidang pemanfaatan ruang terbuka hijau dikarenakan permintaan lahan yang terus meningkat. Permasalahan yang dibahas dalam penulisan ini adalah ruang lingkup ruang terbuka hijau dan akibat hukum mendirikan bangunan pada ruang terbuka hijau di Kota Denpasar? Tipe penelitian yang digunakan dalam penelitian ini adalah yuridis normatif dengan sumber bahan hukum primer dan sekunder. Teknik pengumpulan bahan hukum menggunakan studi kepustakaan yang kemudian dianalisa secara kualitatif. Ruang Terbuka Hijau Kota merupakan ruang-ruang lingkup dalam bentuk area atau jalur yang mendominasi oleh tumbuhan yang berfungsiperlindungan habitat tertentu, dan/atau sarana kota, dan/atau pengaman jaringan prasarana, dan/atau budidaya pertanian sebagaimana yang diatur pada Peraturan Daerah Kota Denpasar Nomor 27 Tahun 2011 Tentang Rencana Tata Ruang Wilayah Kota Denpasar tahun 2011-2031. Selanjutnya, terkait dengan akibat hukum bagi pelanggaran mendirikan bangunan pada ruang terbuka hijau atau pengendalian pemanfaatan ruang wilayah kota adalah berupa sanksi administrasi atas kegiatan pengawasan yang berakibat pada terhambatnya pelaksanaan program pemanfaatan ruang, baik yang dilakukan oleh penerima izin maupun pemberi izin. Jenis sanksi administrasi bagi masyarakat terdiri dari peringatan dan atau teguran, penghentian sementara pelayanan administratif, penghentian sementara kegiatan pembangunan dan atau pemanfaatan ruang, pencabutan izin yang berkaitan dengan pemanfaatan ruang, pemulihan fungsi atau rehabilitasi fungsi ruang, pembongkaran bagi bangunan yang tidak sesuai dengan rencana tata ruang, pelengkapan/pemutihan perizinan, dan pengenaan denda. Terdapat juga sanksi lainnya berupa pidana kurungan paling lama 6 (enam) bulan atau denda paling banyak Rp. 50,000,000, 00, - (Lima puluh juta rupiah).
\end{abstract}

Kata Kunci: Akibat Hukum; Izin Mendirikan Bangunan; Ruang Terbuka Hijau

\begin{abstract}
In this era, urban areas have become a problem that is quite difficult to overcome, especially in the matter of utilization of green open space caused by land demand continuing to increase. The problems discussed in this study are the coverage of green open space and the legal consequences of constructing buildings in green open space in the city of Denpasar. The type of the research used in this study is normative legal research with two types of sources of legal materials, primary and secondary. Data collection was carried out using a literature study which was then analyzed qualitatively. The results show that green open spaces in cities belong to the spaces in the form of areas or paths dominated by plants functioning as protection of certain habitats, city facilities, infrastructure safety networks, and/or agricultural cultivation as regulated in Regional Regulation of Denpasar City Number 27 of 2011 concerning the Spatial Planning for the City of Denpasar in 2011-2031. Furthermore, the legal consequences for violations of erecting buildings in green open spaces or controlling spatial use of urban areas are in the form of administrative sanctions for supervision activities which result in obstruction of the implementation of the spatial utilization program, both carried out by the permit recipient and the licensor. Types of administrative sanctions for the community consist of warnings and/or reprimands, temporary suspension of administrative services, temporary suspension of development activities and/or use of space, revocation of permits relating to spatial use, restoration of functions or rehabilitation of spatial functions, demolition of buildings not in accordance with the plan spatial planning, licensing/whitening, and the imposition of fines. There are also other sanctions in the form of imprisonment for a maximum of 6 (six) months or a maximum fine of IDR. 50,000,000.00, - (fifty million rupiah).
\end{abstract}

Keywords: Legal Consequence; Building Permit; Green Open Space 


\section{PENDAHULUAN}

Demi kebutuhannya, setiap manusia memakan makanan dan meminum minuman yang didapat dari sumber-sumber yang diberikan oleh lingkungan hidup dan kekayaan alam yang tersedia sebagai salah satu sumber daya alam yang penting bagi setiap manusia. Kehidupan manusia tidak terlepas dari lingkungan hidup yang ikut serta untuk membantu dalam kelangsungan hidupnya. Dari tahun ke tahun ruang terbuka hijau mengalami peningkatan secara alami yaitu dalam bidang pemanfaatan yang susah diatasi. Ruang Terbuka Hijau merupakan area yang memanjang berbentuk jalur atau area mengelompok, yang penggunaanya lebih bersifat terbuka, baik yang tumbuh secara alamiah maupun yang tumbuh dengan sengaja ditanam (Budhihardjo \& Sudanti, 1993: 199-200).

Wilayah perkotaan mengendalikan kenyamanan iklim mikro dan keserasian kota yang memerlukan ruang-ruang terbuka untuk memenuhi kebutuhan masyarakat. Semakin berkembangnya jaman dan semakin banyak populasi manusia maka akan menyebabkan keberadaan dari ruang terbuka hijau semakin hari semakin menyempit. Adapun manfaat dari ruang terbuka hijau yaitu sarana yang dipergunakan untuk mencerminkan identitas setiap daerah, sarana penelitian,sarana pendidikan, penyuluhan, rekreasi aktif dan pasif serta interaksi social, dapat meningkatkan nilai ekonomi di perkotaan, menimbulkan rasa bangga dan meningkatkan sarana ruang untuk keadaan darurat, dapat memperbaiki iklim dan meningkatkan cadangan oksigen di perkotaan.

Pada tataran mancanegara, dengan naiknya suhu bumi membuat tidak saja hanya dialami oleh satu pulau, tetapi akan terus menjalar ke pulau-pulau lain, bahkan semakin tipis ruang terbuka itu semakin berakibat fatal bagi bumi, bahkan dapat melampaui batas wilayah tersebut. Ruang terbuka hijau seperti taman, hutan lindung, serta sawah lading dan lain-lain secara fisik dapat dibedakan menjadi tiga bagian tersebut. Dan memiliki fungsi yang sama pula.

Ruang terbuka hijau dibagi menjadi dua yaitu Ruang Terbuka publikdan Ruang Terbuka privat. Ruang Terbuka Hijau publik adalah Ruang Terbuka Hijau yang memiliki dan dikelola oleh pemerintah daerah kabupaten/kota yang digunakan untuk kepentingan masyarakat umum. Contoh Ruang Terbuka Hijau publik adalah taman kota, hutan kota, Ruang Terbuka Hijau disekitar sungai dan pemakaman. Selain itu banyak institusi, instansi, seseorang, yang memiliki ruang terbuka hijau, seperti kebun, halaman, rumah atau Gedung, dan lain-lain (Sutedi, 2015:18).

Adapun ruang terbuka hijau kawasanperkotaan (RTHKP) adalah bagian dari ruang terbuka hijau kawasan perkotaan yang dilengkapi dengan beberapa pertumbuhan dan tanaman untuk mendukung manfaat ekologi, sosial, budaya, dan ekonomi. Ruang terbukahijau yang telah ada secara alami yang telah dibangun antara keseimbangan area dan menciptakan suasana yang serasi, fungsi estetika antara yaitu meningkatkan kenyamanan, fungsi budaya yaitu melihat dari ekspresi budaya lokal, pengatur iklim, paru-paru kota, sebagai peneduh, produsen alam, dan penyedia habitat binatang.

Adapun manfaat dalam ruang terbuka hijau berdasarkan fungsi yang dibagi dalam kategori manfaatlangsung,yaitu membentuk pemeliharaan yang baik, serasi, sebagai pembersih udara, dan melestarikan lingkungan berupa flora dan fauna dan luas kota. Perlu insentif atau intensif jika terjadi atau pelanggaran hukum oleh perorangan dana atau badan dalam pelaksanaan pengembangan ruang terbuka hijau dan disarankan untuk pemerintah untuk membentuk tim audit ruang terbuka hijau untuk menjaga keberadaan dan pelaksanaan pengembangan ruang terbuka hijau (Hastuti, 2011: 56).

Beberapa kajian terkait dengan ruang hijau. Pengaturan hukum dan penataannya telah diluncurkan dalam berbagai jurnal sebagai media publikasi hasil penelitian. Beberapa kajian sebelumnya dapa dilihat dalam penelitian Haris dkk. (2015), Susmitha dkk. (2016), Theis (2016), Salim (2017), Sholihah \& Sabarisman (2018), dan Iqbal (2019). Penelitian-penelitian ini mengkaji tentang tata ruang hijau dari sudut pandang hukum dengan ketentuan Undang-Undang yang berbeda. Namun, terkait dengan ruang lingkup ruang terbuka hijau dan akibat hukum bagi pendirian bangunan pada ruang dimaksud belum disentuh oleh penelitian-penelitian yang sudah ada ini.

Dari uraian pada latar belakang masalah, penelitian kali ini mengakji dua isu: 1) Bagaimana ruang lingkup ruang terbuka hijau? 2) Bagaimana akibat hukum mendirikan bangunan pada ruang terbuka hijau di Kota Denpasar? Tujuan penelitian yaitu: 1) untuk mengetahui ruang lingkup ruang terbuka hijau (RTH); dan 2) untuk mengetahui akibat hukum izin mendirikan bangunan pada ruang terbuka hijau di Kota Denpasar. 


\section{METODE PENELITIAN}

Suatu karya ilmiah akan tersusun secara sistematis, mempunyai arah yang jelas serta pembahasannya teratur. Penelitian ini metode normatif, yaitu penelitian yang mengkaji permasalahan sesuai dengan peraturan perundang-undangan, dan juga menekankan pada segi yuridis (Soekanto \& Manudji, 2007: 14). Pendekatan yang digunakan yaitu Pendekatan Perundang-Undangan (Statute Appoarch) dan Pendekatan Konseptual (Conceptual Appoarch). Pendekatan ini digunakan sebagai pembangunan argumentasi hukum saat menyelesaikan kasus atau isu hukum yang ada di dalam masyarakat, serta pendekatan ini menjadi doktrin dalam perkembangan ilmu hukum.

Sumber bahan hukum dalam penelitian ini dikumpulkan dari penelitian perpustakaan. Dalam hal ini dilakukan dengan beberapa macam sumber atau bahan yang dapat digolongkan ke dalam bahan hukum primer dan bahan hukum sekunder. Pengumpulan data dilakukan melalui studi perpustakaan, yaitu dengan mempelajari dokumen atau bahan bacaan terkait sertifikasi lingkungan \& penataan ruang. Selain itu, data juga dikumpulkan dengan metode mencatat, meringkas serta memberikan ulasan seperlunya terhadap bahan-bahan hukum yang berkaitan dengan pokok permasalahan yang sebelumnya sudah dikatagorikan dan diinventarisasikan berdasarkan klasifikasinya. Data dianalisa secara kualitatif yaitu dengan memilih bahan hukum yang kualitasnya dapat menjawab permasalahan mengenai pelaksanaan dan hambatan dalam jaringan dokumentasi dan informasi hukum. Kemudian bahan hukum disajikan dengan deskriptif analisis yaitu dengan cara menyusun secara sistematis sehingga kesimpulan pun didapatkan.

\section{HASIL PENELITIAN DAN PEMBAHASAN Ruang Lingkup Ruang Terbuka Hijau}

Ruang terbuka adalah ruang suatu ruang yang telah direncanakan untuk kebutuhan aktivitas manusia dalam melakukan kegiatannya. Baik secara individu ataukelompok, serta wadah manusia lainnya untuk hidup dan berkembang secara berkelanjutan sebutkan sebagai fungsi ruang terbuka. Sama dengan pengertiannya, ruang terbuka, ruang terbuka hijau, dan ruang publik memiliki pengertian yang sama. Ruang terbuka seperti taman, kota, dan hutan bisa berbentuk jalan. Ruang Terbuka Hijau adalah daerah jalur yang digunakan lebih bersifatterbuka, tempat tumbuhnya tanaman,secara umum ruang terbuka yang dimiliki dan dikelola oleh pemerintah, memang sengaja ditanam dan dipelihara sebagaimana baiknya agar tidak tercemar dan tetap asri (Purnomohadi, 2006: 27).

Ruang terbuka hijau sebagaimana yang dimaksud dalam pasal 28 huruf a Undang- Undang Nomor 26 tahun 2007 tentang penataan ruang terdiri dari ruang terbuka hijau publik dan ruang terbuka hijau privat. Pada pasal 29 ayat (1) dan ayat (3) disesuaikan dengan adanya persebaran penduduk dan jajaran pelayanan dengan memperhatikan struktur dan pola ruang. Ruang terbuka hijau sebagai ruangterbuka yang pemanfaatannya lebih memacu terhadap perkebunan, pertanian, pertamanan. Ruang terbuka hijau digunakan untuk penetralisir udara, pelindung cahaya matahari, untuk keindahan suatu pusat kota, dan sebagai suatu penghijauan unsur kota.

Menurut Pasal 1 Angka (8) Peraturan Menteri dalam Negeri Nomor 24 Tahun 2006 tentang Pedoman Penyelenggaraan Pelayanan Terpadu Satu Pintu, izin merupakan dokumen penting yang dikeluarkan oleh pemerintah daerah berdasarkan peraturan yang merupakan bukti legalitas sah atau tidaknya suatu badan usaha atau seseorang untuk melakukan kegiatan tersebut. Perizinan didefinisikan sebagai legalitas kepada seseorang atau pelaku usaha atau kegiatan tertentu, baik dalam bentuk izin maupun tanda daftar usaha. Salah satu instrument pemerintah yang memiliki sifat yuridis preventuif, yang digunakan sebagai pengendalian sifat masyarakat, sesuai yang dijelaskan oleh Asep Warlan Yusuf. Pada dasarnya izin merupakan suatu ketetapan atau peraturan yang dibuat oleh pejabat tata usaha negara yang berwenang, yang substansinya memiliki sifat terikat, izin yang bersifat bebas, pribadi, kebendaan, menguntungkan, memberatkan, Izin berlangsung lama, dan Izin yang segera berakhir (Mitchell, 2000:1).

Izin yang memiliki sifatterikat, yaitu izin yang dimana peraturan perundang-undangan tersebut mengaturnya sejauh mana peraturan itu mengatur dan terikat terhadap hukum tertulis maupun hukum tidak tertulis. Dalam memutuskan pemberian izin, yang tidak terikat pada aturan hukum tertulis serta pejabat berwenang yang bersifat bebas. Perizinan yang bersifat pribadi, adalah izin yang isinya mengikut sifat atau kualitas pribadi dan memohon izin. Perizinan yang bersifat kebendaan, merupakan izin yang isinya tergantungpada sifat dan objek izin tersebut. Demi menjaga keamanan 
dan kenyamanan bangunan, penghuni, dan lingkungannya, didirikanlah izin yang berfungsi agar dapat menjaga ketertiban, keselarasan, kepentingan hak atas tanah, maupun kepentingan lainnya yang diperlukan oleh masyarakat.

Suatu surat izin diterbitkan oleh pihak yang berwenang demi suatu legalitas surat izin tersebut, persyaratan yang harus dilengkapi juga berupa persyaratan administrasi, persyaratan teknis, penerbitan bangunan, bangunan komersial, syarat umum bangunan komersial dan legalitas surat izin mendirikan bangunan. Surat izin yang dimaksud yaitu surat izin yang kewenangan untuk melakukan pendirian bangunan itu disahkan oleh Pemerintah Kota, Dinas Tata Ruang dan Perumahan, Dinas Tata Ruang dan Tata Bangunan, dan Unit Pelayanan Terpadu Satu Pintu.

Jika dilihat dari keterkaitan izin mendirikan bangunan dengan peraturan yang mengatur tentang Ruang Terbuka Hijau yaitu, yang menjelaskan bahwa strategi pengendalian perkembangan kegiatan budi daya perkotaan ialah mempertahankan ruang terbuka publik yang sudah ada dan dikembangkan ruang terbuka hijau publik baru di setiap lingkunganpermukiman, pusat Lingkungan, dan Pusat BWK. Ruang terbuka hijau juga termasuk dalam kawasan lindung sebagaimana diatur pada Pasal 37 Peraturan Daerah Kota Denpasar Nomor 27 Tahun 2011.

\section{Akibat Hukum Mendirikan Bangunan pada Ruang Terbuka Hijau di Kota Denpasar}

Akibat hukum bagi pelanggar dikenakan sanksi sesuai aturan yang ada pada aturan hukum Tata Usaha Negara yaitu penjatuhan sanksi administratif. Sehubungan dengan jenis-jenis sanksi hukum administrasi dalam rangka menegakan suatu peraturan daerah, dalam halnya, adapun beberapa jenis sanksi dalam hukum administrasi yaitu paksaan pemerintah, penarikan uang paksa, penarikan keputusan, dan dikenakan sanksi administrtif dengan paksaan pemerintah, dan pengenaan denda administratif bagi yang melanggarnya.

Menurut Peraturan Daerah Kota Denpasar Nomor 27 Tahun 2011, ketentuan mengenai pemanfaatan wilayah diatur dalam pasal 65. Dalam menjalankan prosedur yang benar, mengenai pemanfaatan ruang, yang sesuai dengan arahan pengenaan sanksi nya, pelanggaran yang dilakukan diterbitkan sanksi nya oleh pemerintah berdasarkan Rencana Tata Ruang Wilayah Kota. Jadi, pelanggaran ketentuan tersebut telah ditetapkan dalam pernyataan izin pemanfaatan. Dalam struktur pola dan ruang yang tidak sesuai dengan pengenaan sanksi nya, dikenakan sanksi yang sesuai dengan perbuatan seseorang atau badan tersebut.

Dalam rangka pelaksanaan kegiatan agar tidak terjadinya pelanggaran lagi, penertiban terhadap penataan ruang yang dilakukan terdiri atas pengadilan, instansi, dn masyarakat yang profesionaldan tertib agar dapat menciptakan suatu pelanggaran, dan memberikan sanksi administratif secara lebih tegas. Dalam hal ini diharapkan kepada masyarakat agar mematuhi peraturan sesuai dengan system pengenaan sanksi sesuai dengan aturan perundang-undangan, arahan sesuai zonasi, dan memberikan insentif atau disinfektif.

\section{SIMPULAN DAN SARAN}

\section{Simpulan}

Dari penjelasan pendahuluan sampai dengan hasil penelitian dan pembahasan, maka dapat disimpulkan yaitu:

a. Peraturan Daerah Kota Denpasar Nomor 27 Tahun 2011 Tentang Rencana Tata Ruang Wilayah Kota Denpasar mengatur mengenai ruang lingkup Ruang Terbuka Hijau di Kota Denpasar, yang dibagi menjadi Ruang Terbuka Hijau Publik dan Ruang Terbuka Privat. Ruang Terbuka Publik dalam hal ini dikembangkan sekitar 2.480 Ha dari luas wilayah kota yang berupa jalur hijau, sungai, hutan, jalan raya, dan area persawahan. Ruang Terbuka Privat dalam hal ini dikembangkan sebanyak 2.220 Ha dari luas area yang berupa pekarangan rumah, taman kota, kebun, dan lain-lain.

b. Akibat hukum mendirikan bangunan pada ruang terbuka hijau, pelanggaran pemanfaatan ruang wilayah kota,menurut hasil dari pengawasan dari pemerintah, dilakukan penerimaan izin maupun memberikan izin, hal ini diakibatkan pada hambatan program pemanfaatan ruang dengan pelaksanaannya. Sanksi yang ada lama hal ini ialah diberikan sanksi administratif, pencabutan izin, pengenaan denda, pemutihan perizinan, pemulihan fungsi atau rehabilitasi fungsi ruang, dan penghentian pembangunan sementara. Selain adanya sanksi administratif, 
terdapat juga sanksi pidana yaitu kurungan penjara paling lama 6 bulan atau dikenakan denda sebanyak Rp. 50.000.000.00-,

\section{Saran}

Dalam hal ini diperlukan perilaku yang tegas dari pemerintah untuk menerapkan sanksi-sanksi bagi pihak yang melakukan pelanggaran pendirian bangunan pada ruang terbuka hijau atau pemanfaatan ruang wilayahkota berupa peringatan atau teguran, diberhentikan sementara pelayanan administratif dan kegiatan pembangunan atau pemanfaatan ruang, pencabutan izin ruang terbuka, mengalihfungsikan atau merehabilitasi fungsi ruang, pengenaan denda pencabutan izin, dan pembongkaran bagi bangunan yang tidak sesuai terhadap yang melanggar peraturan tersebut.

Masyarakat perlu untuk memahami dan melaksanakan prosedur mendirikan bangunan dan tidak melakukan pelanggaran terhadap ruang terbuka hijau dan pemanfaatan ruang wilayah kota.Dan masyarakat juga perlu untuk memahami dan melaksanakan peraturan-peraturan yang berlaku baik peraturan walikota, peraturan daerah, dan lain sebagainya yang terkait dengan mendirikan bangunan dan pemanfaatan ruang wilayah kota, agar tidak terjadinya pelanggaran-pelanggaran terhadap ketentuan yang berlaku.

\section{DAFTAR PUSTAKA}

Budhihardjo, E., \& Sudanti. (1993). Kota Berwawasan Lingkungan. Penerbit Alumni.

Haris, H. S., Sucipto, \& Effendi, L. (2015). Efektifitas Pasal 16 Peraturan Daerah Nomor 4 Tahun 2011 tentang Rencana Tata Ruang Wilayah Kota Malang Tahun 2010-2030 Terkait Dengan Ruang Terbuka Hijau Bagi Masyarakat (Studi di Badan Perencanaan Pembangunan Daerah \& Dinas Kebersihan dan Pertamanan Kot. Jurnla Ilmu Hukum, Maret(2), 1-20.

Hastuti, E. (2011). Kajian Perencanaan RTH Perumahan. Raja Grafindo.

Iqbal, M. (2019). Pengelolaan Ruang Terbuka Hijau Berdasarkan Peraturan Daerah Kota Padang No 3 Tahun 2017. Ranah Research: Journal of Multidisclipinary Research and Development, 1(2), $125-252$.

Mitchell, B. (2000). Pengelolaan Sumber Daya dan Lingkungan. Gajah Mada University Press.

Purnomohadi, N. (2006). Ruang Terbuka Hijau Sebagai Unsur Utama Tata Ruang Kota. Direktorat Jenderal Penataan Ruang, Departemen Pekerjaan Umum.

Salim, M. (2017). Analisis Kebijakan Pengadaan Ruang Terbuka Hijau Melalui PERDA No. 10 Tahun 2012 Tentang Rencana Tata Ruang Wilayah Kabupaten Tegal Tahun 2012-2032. Journal of Politic and Government Studies.

Sholihah, I., \& Sabarisman, M. (2018). Pemenuhan Kesejahteraan Sosial Melalui Optimalisasi Ruang Terbuka Hijau (Rth) Di Kawasaan Perkotaan Dalam Perspektif Hukum Dan Kebijakan. Sosio Informa, 4(1), 297-312.

Soekanto, S., \& Manudji, S. (2007). Penelitian Hukum Normatif: Suatu Tinjauan Singkat. PT. Raja Grafindo Persada.

Susmitha, N. P. P. W., Sudiarta, I. K., \& Sarna, K. (2016). Pelaksanaan Peraturan Daerah Kota Denpasar Nomor 27 Tahun 2011 Terkait Bangunan Di Ruang Terbuka Hijau Kota Denpasar. Kertha Negara: Jurnal Ilmu Hukum, 04(05), 1-5.

Sutedi, A. (2015). Hukum Perizinan dalam Sektor Pelayanan Publik. Sinar Grafika.

Theis, G. A. (2016). Analisis Hukum atas Penataan Ruang Terbuka Hijau di Kota Manado. Lex Administratum, 4(1), 13-20. 